University of Nebraska - Lincoln

DigitalCommons@University of Nebraska - Lincoln

\title{
Influence of Age, Sex, and Calcium and Phosphorus Levels on the Mechanical Properties of Various Bones in Swine
}

\author{
T. D. Crenshaw \\ University of Wisconsin \\ E. R. Peo, Jr. \\ University of Nebraska-Lincoln
}

A. J. Lewis

University of Nebraska-Lincoln, alewis2@unl.edu

B. D. Moser

University of Nebraska-Lincoln

D. Olson

lowa State University

Follow this and additional works at: https://digitalcommons.unl.edu/animalscifacpub

Part of the Animal Sciences Commons

Crenshaw, T. D.; Peo, Jr., E. R.; Lewis, A. J.; Moser, B. D.; and Olson, D., "Influence of Age, Sex, and Calcium and Phosphorus Levels on the Mechanical Properties of Various Bones in Swine" (1981). Faculty Papers and Publications in Animal Science. 658.

https://digitalcommons.unl.edu/animalscifacpub/658

This Article is brought to you for free and open access by the Animal Science Department at DigitalCommons@University of Nebraska - Lincoln. It has been accepted for inclusion in Faculty Papers and Publications in Animal Science by an authorized administrator of DigitalCommons@University of Nebraska - Lincoln. 


\title{
INFLUENCE OF AGE, SEX AND CALCIUM AND PHOSPHORUS LEVELS ON THE MECHANICAL PROPERTIES OF VARIOUS BONES IN SWINE ${ }^{1,2}$
}

\author{
T. D. Crenshaw ${ }^{3}$, E. R. Peo, Jr., A. J. Lewis, B. D. Moser and D. Olson ${ }^{4}$ \\ University of Nebraska, Lincoln 68583
}

\begin{abstract}
Summary
Seventy-two 4-week-old pigs were randomly assigned by sex (gilts, barrows, boars) to two dietary treatments and four age periods for determinations of the effects of age, sex and $\mathrm{Ca}$ and $\mathbf{P}$ levels on the mechanical properties of various bones in swine. Pigs were individually fed diets containing either .4, .4\% Ca,P (T1) or $.8, .8 \% \mathrm{Ca}, \mathrm{P}(\mathrm{T} 2)$. Slaughter times (age period) were approximately 1 (A1), 3 (A3), 5 (A5) and 7 (A7) months after the initiation of the trial. The femur (Fem), humerus (Hum), third and fourth metacarpal (3MC, 4MC), third and fourth metatarsal (3MT, 4MT), third rib (Rib) and thoracic vertibrae were collected at each age period for mechanical tests and determination of percentage of ash. Bending moment, ultimate stress, yield stress and modulus of elasticity were determined by a flexure test in which the bone was treated as a simply supported, centrally-loaded beam (three-point loading). Bending moment of bones from boars was similar to that of bones from gilts or barrows. When expressed as force per unit area, the ultimate stress of bones from boars was less than that of bones from gilts or barrows. Percentage of ash did not differ significantly between sexes, but tended to be lower in bones from boars than in bones from gilts or barrows. Bones from pigs fed $\mathrm{T} 2$ had a higher bending moment than bones from pigs fed $\mathrm{T} 1$, regardless of age. At $\mathrm{A} 1$, the Fem, Hum and Rib of pigs
\end{abstract}

\footnotetext{
${ }^{1}$ Published as Paper No. 6094, Journal Ser., Nebraska Agr. Exp. Sta.

${ }^{2}$ Dept. of Anim. Sci. Acknowledgment is made to Chuck Clanton for assistance with engineering equations and to Cecilia Stodd and Mary Barnes for laboratory assistance.

${ }^{3}$ Current address: Meat and Anim. Sci. Dept., Univ. of Wisconsin, Madison.

${ }^{4}$ Current address: Anim. Sci. Dept., Iowa State Univ., Ames.
}

fed $\mathrm{T} 2$ were able to withstand a greater stress than the same bones of pigs fed T1. At A3 and A5, the ultimate stress of all bones increased with increasing levels of dietary $\mathrm{Ca}, \mathrm{P}$. At A7, the Fem, $4 M T$ and Rib failed to show a response to increased levels of $\mathrm{Ca}, \mathrm{P}$.

(Key Words: Bone, Sex, Age, Calcium, Phosphorus, Swine.)

\section{Introduction}

The physical characteristic, strength, has been used by nutritionists to assess mineralization of bones. Burnett (1908) used bone strength to demonstrate the value of $P$ in feedstuffs for swine. More recently, Hayes et al. (1979) concluded that bone strength was the best trait from which to estimate the bioavailability of dietary $\mathbf{P}$.

The ideal bone(s) for assessing mineralization in swine may vary with age, sex and possibly other biological as well as economical factors. For example, bones from the front or hind feet are more accessible and economically more appealing for testing than is the femur or humerus. Tanksley (1979) implied that the femur is a better indicator of bone development than are metacarpal bones, and that $\mathrm{Ca}$ and $\mathrm{P}$ requirements for maximum bone development differ widely, depending upon the bone used. Henrikson (1968) demonstrated in dogs that vertebrae and then ribs are depleted of $\mathrm{Ca}$ before long bones. Using ${ }^{45} \mathrm{Ca}$, Pond et al. (1969) reported similar activity among vertebrae, mandibles, nasal turbinates and the proximal and distal ends of both the femur and humerus of young pigs.

Researchers have recently reported that boars have a $\mathrm{Ca}-\mathrm{P}$ requirement for maximum bone breaking strength higher than current NRC (1973)-recommended levels of optimum growth (Tanksley et al., 1976; Nimmo et al., 1980). For the most part, NRC-recommended levels for $\mathrm{Ca}$ and $\mathrm{P}$ have been based on research 
with growing-finishing barrows and gilts. Little work has been done to determine directly the effect of sex on the mechanical properties of bone.

The purpose of the research reported herein was to determine the influences of age, sex and Ca-P levels on the mechanical properties of various bones in swine.

\section{Materials and Methods}

Seventy-two 4-week-old crossbred pigs were randomly assigned by sex (gilts, barrows, boars) to two dietary treatments and four age periods. Pigs were individually fed a $16 \%$ corn-soybean meal basal diet (table 1) containing either .4, $.4 \%(\mathrm{~T}-1)$ or $.8, .8 \%(\mathrm{~T}-2) \mathrm{Ca}$ and $\mathrm{P}$. Pig weights and feed consumption were measured biweekly. Pigs were housed in an environmentally regulated building with $1.07 \mathrm{~m} \times 1.52 \mathrm{~m}$ individual pens and completely slatted concrete floors. The age periods designated for study were 1 (A1), 3 (A3), 5 (A5) and 7 (A7) months after the initiation of the trial, but the pigs were actually slaughtered at $18,82,145$ and 192 days of age.

At slaughter, eight bones were collected for the determination of mechanical properties and percentage of ash. The bones were all from the right side and consisted of the femur ( $\mathrm{Fem})$, humerus (Hum), third and fourth metacarpal (3MC, 4MC), third and fourth metatarsal (3MT, $4 M T$ ), third rib (Rib) and the right half of the thoracic vertebra (Ver) located at the third rib. Bones were cleaned of adhering tissue by autoclaving at $116 \mathrm{C}$ and $1.3 \mathrm{~kg} / \mathrm{cm}^{2}$ pressure. Depending upon the amount of tissue surrounding the bone, the time of autoclaving was adjusted so that blood around the bone itself was still bright red. We considered the bones to be "raw bones" even though they had been exposed for a short time to autoclaving. Before and after cleaning, bones were stored at $-28 \mathrm{C}$ in plastic bags to maintain the original moisture content. After mechanical tests and measurements were made, the bones were extracted in anhydrous ethyl-ether for removal of lipid material and then ashed at $600 \mathrm{C}$.

The mechanical properties of all bones except the vertebrae were determined by a flexure test with an Instron Universal Testing Machine $^{5}$. The flexure test has been widely used for determining the mechanical properties

\footnotetext{
${ }^{5}$ Model 1123, Instron Corp., Canton, MA 02021.
}

TABLE 1. COMPOSITION AND ANALYSIS OF DIETS

\begin{tabular}{|c|c|c|}
\hline \multirow[b]{2}{*}{ Ingredient } & \multicolumn{2}{|c|}{$\% \mathrm{Ca}, \mathrm{P}$} \\
\hline & $.4, .4$ & $.8, .8$ \\
\hline \multicolumn{3}{|l|}{ Corn, yellow } \\
\hline \multicolumn{3}{|l|}{ Soybean meal } \\
\hline $\begin{array}{l}\text { Dicalcium phosphat } \\
\text { (IFN 6-01-080) }\end{array}$ & .60 & 2.92 \\
\hline \multicolumn{3}{|l|}{ Limestone } \\
\hline Trace mineral mix ${ }^{a}$ & .10 & .10 \\
\hline Selenium premix ${ }^{a}$ & .05 & .05 \\
\hline \multicolumn{3}{|l|}{ Salt, iodized } \\
\hline \multirow[t]{2}{*}{ Vitamin premix $b$} & 1.0 & 1.0 \\
\hline & 100.00 & 100.00 \\
\hline \multicolumn{3}{|l|}{ Chemical analysis: } \\
\hline Dry matter, \% & 87.8 & 87.9 \\
\hline Protein, \% & 15.6 & 15.4 \\
\hline $\mathrm{Ca}, \%$ & .41 & .82 \\
\hline $\mathbf{P}, \%$ & .44 & .86 \\
\hline
\end{tabular}

${ }^{a}$ Contributed the following in milligrams/kilogram of diet: $\mathrm{Zn}, 200 ; \mathrm{Fe}, 100 ; \mathrm{Mn}, 55 ; \mathrm{Cu}, 10 ; \mathrm{Co}, 1.0$; I, 1.5; sodium selenite, .1.

${ }^{b}$ Contributed the following per kilogram of diet: vitamin $A, 3,300 \mathrm{IU}$; vitamin $\mathrm{D}_{3}, 440 \mathrm{IU}$; riboflavin, $2.2 \mathrm{mg}$; d-pantothenic acid, $13.2 \mathrm{mg}$; niacin, $17.6 \mathrm{mg}$; choline chloride, $110 \mathrm{mg}$; vitamin $B_{12}, .022 \mathrm{mg}$; ethoxyquin, $4.4 \mathrm{mg}$; menadione sodium bisulfate, $2.2 \mathrm{mg}$; vitamin E, $22 \mathrm{IU}$.

of bones (Baker and Haugh, 1979). The bone was treated as a beam supported at each end and a force was applied at midshaft. Force was applied at a constant rate $(5 \mathrm{~mm} / \mathrm{min})$ to all bones, and a recorder was used to plot the force-deflection curve (figure 1), where chart movement was proportional to crosshead movement. The test was stopped when the curve leveled of $f$ or reached a peak or maximum force, and the ultimate stress of the bone was determined. Although most bones did not break apart at this point, if further deformation of bending occurred, the bone failed to withstand any greater increase in force, as indicated by the dashed line portion of the curve beyond point $A$ (figure 1 ).

In the initial phase of the curve, force increased in a linear fashion and was proportional to deformation. It is during this phase that elastic deformation occurs (Evans, 1973), and up 


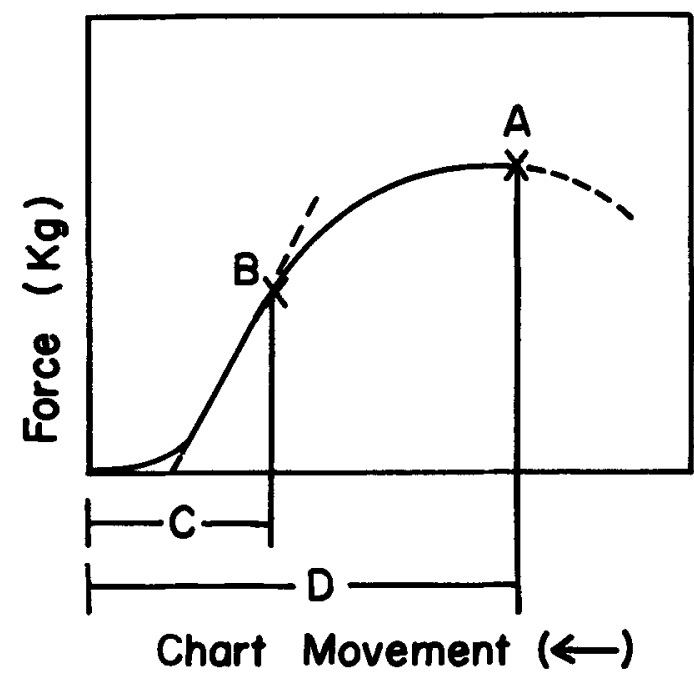

Figure 1. Typical force-deformation curve recorded in mechanical test of bone, $A=$ peak force, kilograms. $\mathrm{B}=$ inflection force, kilograms. $\mathrm{C}=$ deformation to inflection point, millimeters. $D=$ deformation to peak point, millimeters.

to the inflection point no permanent damage is done to the bone. At the inflection point, maximum yield stress can be determined. Beyond the inflection point, permanent damage is done to the bone, or plastic deformation is exhibited.

Measurements were made at the point of loading (midshaft) to determine outside and inside diameters of the bones. Impressions were made of the cross sections of a representative portion of each bone, and the moment of inertia was calculated according to the method of Granik and Stein (1973). Diameters of the cross sections were used in equations for calculating the moment of inertia of known shapes, and the equation with the lowest percentage error was then used for that bone (figure 2). By this method, we determined that the equation for the moment of inertia of an ellipse more closely fits the shape of the femur and humerus, while the equation for an elliptical quadrant more closely fits the metacarpal, metatarsal and rib.

Equations used for calculating the various strength parameters involving elliptical cross sections have been reported by Weir et al. (1949). Equations used for bones with a cross section of an elliptical quadrant were taken from an engineering handbook by Griffel (1966).
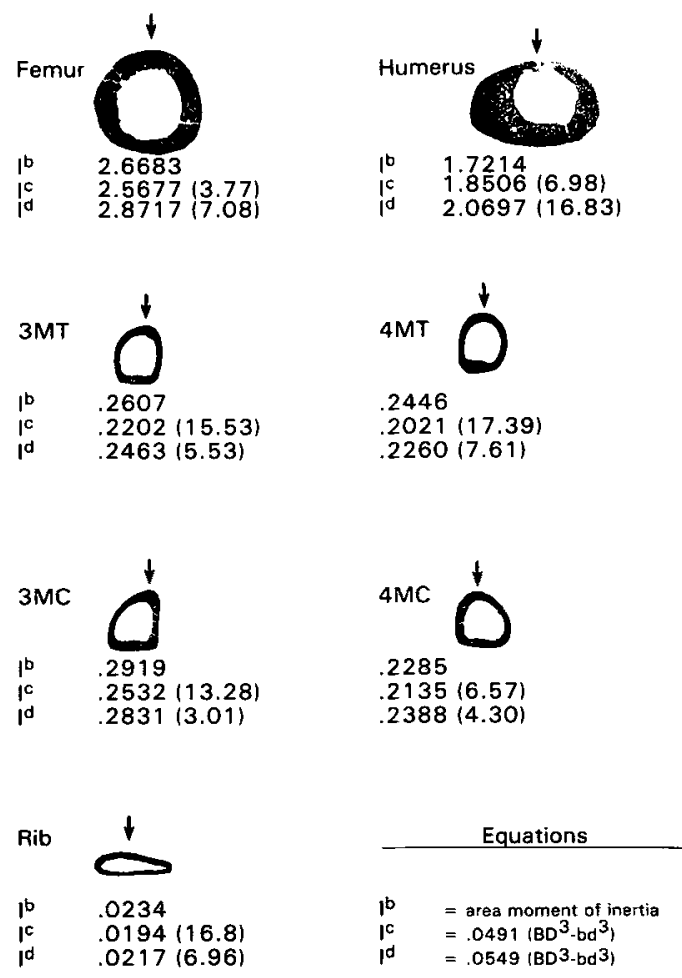

Figure 2. Determination of equations used for calculating the moment of inertia of various bone cross sections. The number in parentheses is the percentage difference from $I^{b} \cdot I^{b}=$ the area moment of inertia about the neutral axis determined by procedure used by Granik and Stein (1973). $\mathrm{I}^{\mathrm{c}}=$ moment of inertia determined with the equation for an ellipse. $B$ and $b$ are outside and inside diameters perpendicular to the direction of force, while $D$ and $d$ are diameters parallel to the direction of applied force. The arrow inidcates the direction of applied force. $I^{d}=$ moment of inertia determined with the equation for an elliptical quadrant with the diameters determined as above.

Bending moment is simply an adjustment of the force applied to the bone to account for differences in the span over which the force is applied. It is determined by the formula,

Bending moment (kilograms-centimeters $)=$

$$
\frac{\text { force } \times \text { length }}{4} \text {, }
$$

where length equals the distance between the two fulcra points that support the bone. Bending moment allows comparisons of force to be made between bones of different lengths.

Stress is force per unit area. The area moment of inertia accounts not only for differences in 
area, but also for differences in shape of the bone cross section through which the force is applied (table 2). Stress is calculated as follows:

$$
\begin{aligned}
& \text { Stress (kilograms/square centimeter })= \\
& \frac{\text { force } \times \text { length } \times \mathrm{C}}{4 \times \text { moment of inertia }}
\end{aligned}
$$

where $\mathrm{C}$ equals the distance from the neutral axis to the extreme fiber. For an ellipse, C equals one-half the diameter that is parallel to the force applied. For an elliptical quadrant, $C$ equals the diameter minus four times the diameter divided by $3 \pi$. Stress allows comparisons to be made between strengths of bones that differ in length, size and shape.

Strain takes into account the amount of bending or deformation that occurs in the bone as it is being tested. The formula by which it is determined is

$$
\begin{gathered}
\begin{array}{c}
\text { Strain }= \\
12 \times \text { deformation } \times \mathrm{C}
\end{array} \\
\text { length }^{2}
\end{gathered}
$$

Strain is unitless, as it is the change in length per unit length.

Modulus of elasticity is the force per unit area (stress) per unit of bending (strain), or more simply the stress:strain ratio:

$$
\begin{gathered}
\text { Mod. elas. }= \\
\frac{\text { Force } \times \text { length }^{3}}{48 \times \text { moment inertia } \times \text { deformation }} .
\end{gathered}
$$

Modulus of elasticity is a measure of the ability of a bone to return to its original shape and is an indicator of the stiffness or rigidity of the bone.

Each parameter was calculated at both the inflection point or peak by substituting either the inflection force or peak force and the deformation at either the peak or inflection point.

The vertebrae were tested by a method similar to a hardness test (Evans, 1973). A section

\begin{tabular}{|c|c|c|c|c|c|c|c|c|}
\hline \multirow[b]{3}{*}{ Age } & \multirow[b]{3}{*}{ Measure } & \multirow{3}{*}{$\begin{array}{l}\text { No. of } \\
\text { animals }\end{array}$} & \multicolumn{6}{|c|}{$\% \mathrm{Ca}, \mathrm{P}$} \\
\hline & & & \multicolumn{3}{|c|}{$.4, .4$} & \multicolumn{3}{|c|}{$.8, .8$} \\
\hline & & & Gilts & Barrows & Boars & Gilts & Barrows & Boars \\
\hline \multirow[t]{4}{*}{ A1 } & & 72 & & & & & & \\
\hline & ADG, $\mathrm{kg}$ & & .25 & .28 & .31 & .29 & .27 & .31 \\
\hline & ADFI, $\mathrm{kg}$ & & .59 & .66 & .67 & .72 & .64 & .69 \\
\hline & $F / G$ & & 2.64 & 2.96 & 2.30 & 2.60 & 2.48 & 2.34 \\
\hline \multirow[t]{4}{*}{ A3 } & & 54 & & & & & & \\
\hline & ADG, $\mathrm{kg}$ & & .61 & .60 & .64 & .63 & .63 & .65 \\
\hline & ADFI, kg & & 1.41 & 1.38 & 1.46 & 1.45 & 1.49 & 1.46 \\
\hline & $\mathrm{F} / \mathrm{G} \mathrm{c}$ & & 2.31 & 2.33 & 2.28 & 2.33 & 2.36 & 2.23 \\
\hline \multirow[t]{4}{*}{ A5 } & & 36 & & & & & & \\
\hline & ADG, kgbb & & .66 & .73 & .78 & .69 & .70 & .77 \\
\hline & ADFI, kgbb & & 1.81 & 2.02 & 2.03 & 2.00 & 2.12 & 2.03 \\
\hline & F/Gecd & & 2.76 & 2.78 & 2.61 & 2.89 & 3.02 & 2.64 \\
\hline \multirow[t]{4}{*}{ A7 } & & 18 & & & & & & \\
\hline & ADG, $\mathbf{k g} \mathrm{bbcc}$ & & .61 & .68 & .79 & .64 & .68 & .80 \\
\hline & ADFI, kgbbd & & 2.02 & 2.27 & 2.38 & 2.28 & 2.48 & 2.50 \\
\hline & F/G $\mathbf{G}^{b}$ bed & & 3.33 & 3.36 & 3.01 & 3.58 & 3.65 & 3.13 \\
\hline
\end{tabular}
was cut from the right half of each vertebra so that the bone fitted a v-shaped base when tested. Tests were made midventrically on the vertebra body. A small probe $1.8 \mathrm{~mm}$ in diam-

TABLE 2. GAIN AND FEED CONVERSION OF PIGS AS INFLUENCED BY AGE, SEX AND CALCIUM-PHOSPORUS LEVELS ${ }^{\mathrm{a}}$

\footnotetext{
${ }^{a}$ Adjusted for differences in initial weight. Average initial weight, 9 kilograms.

${ }^{b}$ Gilts different $(P<.05)$ from barrows and boars.

${ }^{b b}$ Gilts different $(P<.01)$ from barrows and boars.

${ }^{c_{B}}$ arrows different $(P<.05)$ from boars.

${ }^{c c_{B}}$ arrows different $(P<.01)$ from boars.

${ }^{\mathrm{d}} \mathrm{Ca}, \mathrm{P}$ level effect $(\mathrm{P}<.01)$.
} 


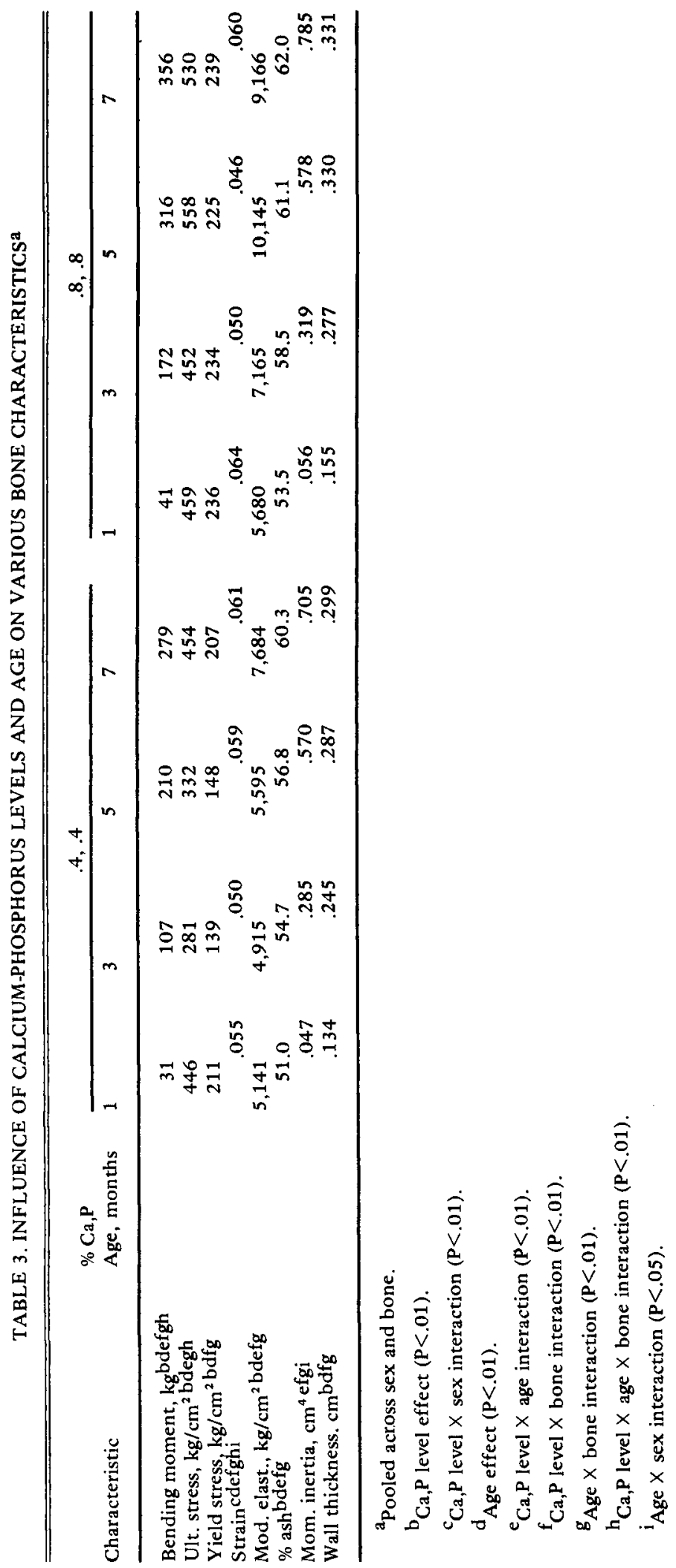


eter was used to ensure total contact with surface of the bone. Rate of deformation was the same as that used for other bones $(5 \mathrm{~mm} /$ $\min$ ), and the force required to puncture the bone was measured. Thickness of the cortical bone at the puncture site was measured and used for calculating maximum shear stress in the following equation:

Shear stress (kilograms/square centimeter) $=$

$$
\frac{\text { force }}{\pi \mathrm{dh}} \text {, }
$$

where $\pi \mathrm{d} h$ is the area of a spherical segment with $d$ the diameter of the probe and $h$ the thickness of the cortical bone. Shear stress is force per unit area. Percentage of ash was determined as for the other bones on the section of vertebra tested.

Statistical analyses were conducted by split-plot analysis (Steel and Torrie, 1960); animals fed the various $\mathrm{Ca}-\mathrm{P}$ levels, sex and age were the main plots and bones the subplot units. Covariable analyses were used to test the homogeneity of slopes between various parameters as affected by main plot units (Barr $e t$ al., 1976).

\section{Results and Discussion}

Growth Performance. Growth and feed efficiency responses of pigs are shown in table 2 by age, sex and $\mathrm{Ca}, \mathrm{P}$ level. At $\mathrm{A} 1$, there were no differences in growth rate or feed efficiency due to sex. At A3, there were no differences in growth rate due to sex, but boars were more efficient $(\mathrm{P}<.05)$ than barrows or gilts. Boars and barrows gained at a faster rate $(P<.01)$ than gilts at A5; the boars were more efficient $(\mathrm{P}<.01)$ in feed conversion than the barrows and the gilts. At A7, boars gained faster and more efficiently than barrows $(P<.01)$, and barrows gained faster $(P<.01)$ and more efficiently $(\mathrm{P}<.05)$ than gilts.

$\mathrm{Ca}, \mathrm{P}$ level did not affect growth rate at any age period. However, at $\mathrm{A} 5$ and $\mathrm{A} 7$, pigs fed $T 1$ were more efficient $(P<.01)$ than those fed $\mathrm{T} 2$. One pig assigned to $\mathrm{A} 5$ and fed $\mathrm{T} 1$ was slaughtered early because of a spontaneous fracture of its right femur. Two other pigs fed $\mathrm{T} 1$ and assigned to A5 broke bones during shipment to slaughter. Bones were collected from these three animals, but it was sometimes necessary to use a bone from the left side rather than the right side.

Bone Properties. The results of the mechanical tests on all bones except the vertebrae, along with their ash content and some geometrical measurements, are shown in tables 3,4 and 5 . The data have been pooled to indicate the main effects, although significant interactions did occur as noted in the footnotes. Subsequent discussion and figures will deal with these interactions. Mechanical tests used to

TABLE 4. INFLUENCE CALCIUM-PHOSPHORUS LEVELS AND SEX ON VARIOUS BONE CHARACTERISTICS ${ }^{a}$

\begin{tabular}{|c|c|c|c|c|c|c|}
\hline \multirow[b]{2}{*}{ Characteristic } & \multicolumn{3}{|c|}{$.4, .4 \%$} & \multicolumn{3}{|c|}{$.8, .8 \%$} \\
\hline & Gilts & Barrows & Boars & Gilts & Barrows & Boars \\
\hline Bending moment, $\mathrm{kg} / \mathrm{cm}^{f}$ & 165 & 148 & 157 & 230 & 214 & 220 \\
\hline Ult. stress, $\mathrm{kg} / \mathrm{cm}^{2} \mathrm{bf}$ & 428 & 366 & 340 & 545 & 501 & 454 \\
\hline Yield stress, $\mathrm{kg} / \mathrm{cm}^{2}$ bf & 196 & 178 & 154 & 256 & 233 & 211 \\
\hline Strainbed & .054 & .058 & .057 & .054 & .051 & .059 \\
\hline Mod. elast., $\mathrm{kg} / \mathrm{cm}^{2} \mathrm{bf}$ & 6,401 & 5,648 & 5,453 & 8,511 & 8,147 & 7,460 \\
\hline$\%$ ash & 56.0 & 55.8 & 55.3 & 59.0 & 59.0 & 58.3 \\
\hline Mom. inertia, $\mathrm{cm}^{4} \mathrm{bce}$ & .348 & .394 & .463 & .377 & .424 & .503 \\
\hline Wall thickness, $\mathrm{cm}$ & .240 & .241 & .244 & .265 & .267 & .287 \\
\hline
\end{tabular}

${ }^{\mathrm{a}}$ Pooled across age and bone.

${ }^{b}$ Sex effect $(P<.01)$.

${ }^{c}$ Sex $X$ age interaction $(P<.01)$,

$\mathrm{d}_{\text {Sex }} \times \mathrm{Ca}, \mathrm{P}$ level interaction $(\mathrm{P}<.01)$.

$\mathrm{e}_{\mathrm{Sex}} \mathrm{X}$ bone interaction $(\mathrm{P}<.01)$.

$f_{C a, P}$ level effect $(P<, 01)$. 


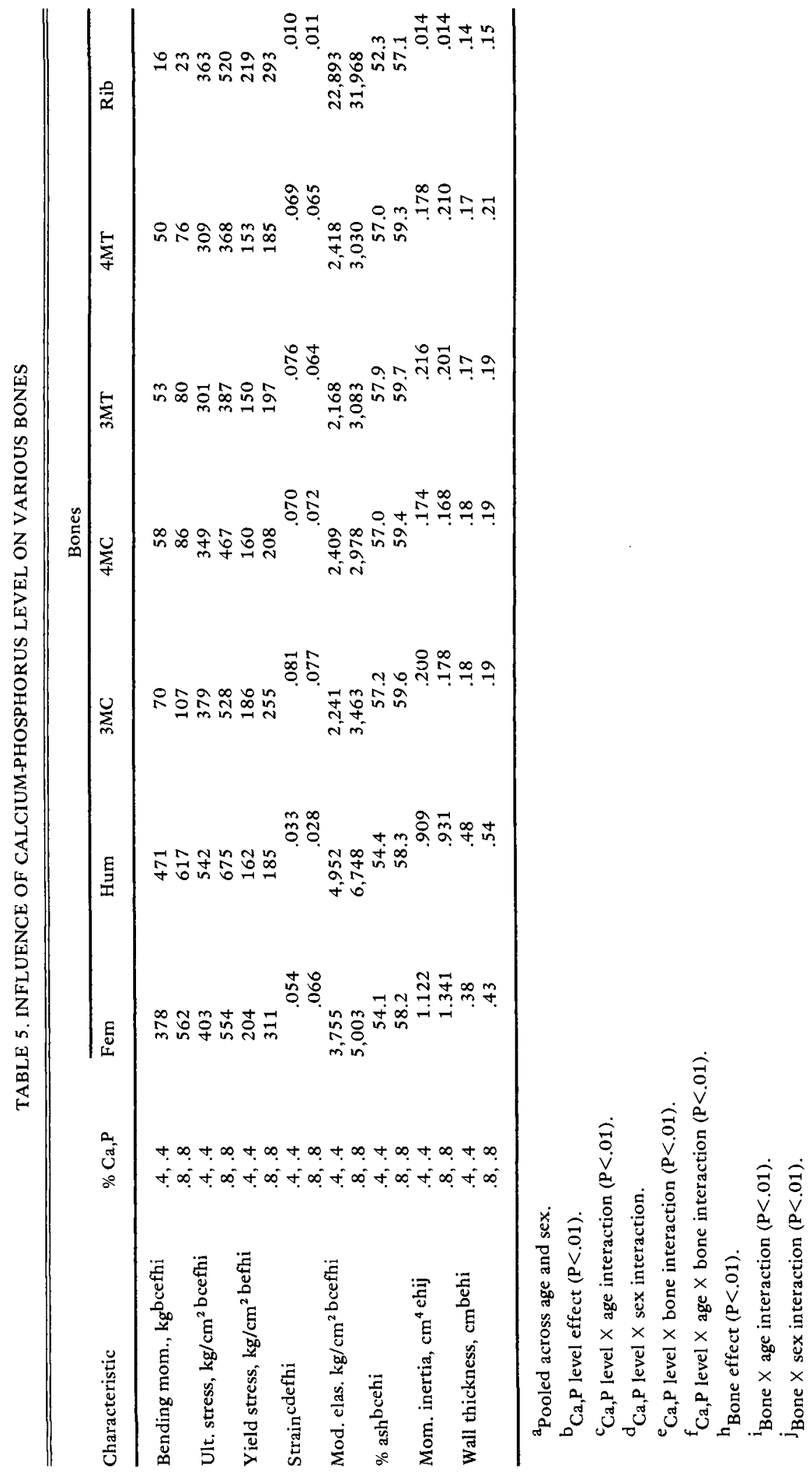


determine the strength of vertebrae were different from those used for other bones; thus, the results of these tests are presented separately in table 6.

When pooled across bone and sex, the data indicate that the feeding of higher levels of $\mathrm{Ca}, \mathrm{P}$ resulted in an increase in the mechanical properties (bending moment, ultimate stress, yield stress and modulus of elasticity), geometrical measurements (moment of inertia and wall thickness) and percentage of ash of bones (table 3 ). Other researchers have also reported an increase in bone strength due to an increase in the level of $\mathrm{Ca}$ and $\mathrm{P}$ fed (Miller et al., 1962, 1964; Libal et al., 1969; Cromwell et al., 1972; Tanksley et al., 1976; Nimmo et al., 1980). Interactions did occur which indicated that the response of each bone to $\mathrm{Ca}, \mathrm{P}$ level was not the same across the age periods evaluated in this study.

With both levels of $\mathrm{Ca}, \mathrm{P}$, bending moment and moment of inertia of bones increased linearly across all age periods. When expressed as force per unit area, ultimate stress was lower at $\mathrm{A} 3$ than at $\mathrm{A} 1$ for pigs fed either level of $\mathrm{Ca}, \mathrm{P}$, although the decrease was not as great for pigs fed $\mathrm{T} 2$ as it was for pigs fed T1. The decrease in ultimate stress differed depending upon which bone was considered; this will be discussed in more detail later. At A5 and A7, bones from pigs fed $\mathrm{T} 1$ showed an increase in ultimate stress, while bones from pigs fed T2 had a similar ultimate stress at these ages.

For pigs fed $\mathrm{T} 1$, yield stress of bones in response to ultimate stress was similar across all age periods. Likewise, yield stress of bones from pigs fed $\mathrm{T} 2$ did not differ due to age.

Like stress, the modulus of elasticity decreased at A3 then increased at A5 and A7 for bones from pigs fed $\mathrm{T} 1$, while for bones from pigs fed $\mathrm{T} 2$, the modulus of elasticity increased linearly up to A5 and then leveled off between A5 and $A 7$.

Percentage of ash and wall thickness increased linearly for bones from pigs fed $\mathrm{T} 1$ across all age periods, but among pigs fed $\mathrm{T} 2$, percentage of ash and wall thickness were similar at A5 and A7. Interactions did occur which indicate that not all bones responded similarly at each age period or $\mathrm{Ca}, \mathrm{P}$ level.

There were no differences due to sex in the amount of force (bending moment) that the bones withstood (table 4). Bones from boars had a larger moment of inertia than bones from barrows or gilts, and when force was expressed per unit of bone area, bones from boars had a lower ultimate and yield stress $(\mathrm{P}<.01)$ than those for barrows, while bones from gilts withstood the greatest stresses. The lower stress indicates that the boars had bones that were less mineralized than those of gilts or barrows and that the boars compensated for this lower strength by the increase in moment of inertia. This hypothesis is supported by a trend toward a lower percentage of ash in bones from boars than in bones from gilts or barrows. Liptrap et al. (1970) reported no difference in bending moment between bones from gilts and boars, but when stress was calculated, boars were found to have weaker bones than gilts. In contrast, Swanson (1971) indicated that human males had stronger bones than females. Martin and Atkinson (1977) attributed the stronger bones of males to an increase in moment of inertia; in females, the moment of inertia, as well as strength, declined after 30 years of age. Bones had a lower strength regardless of the level of $\mathrm{Ca}, \mathrm{P}$ fed, but all sexes responded in a positive manner to increasing levels of $\mathrm{Ca}, \mathrm{P}$.

Shown in table 5 are the results of the mechanical testing of all bones (except the vertebrae) for each $\mathrm{Ca}, \mathrm{P}$ level. The results have been pooled across sex and age. The Hum withstood the greatest force (bending moment) regardless of $\mathrm{Ca}, \mathrm{P}$ level fed. The MC and MT bones had a

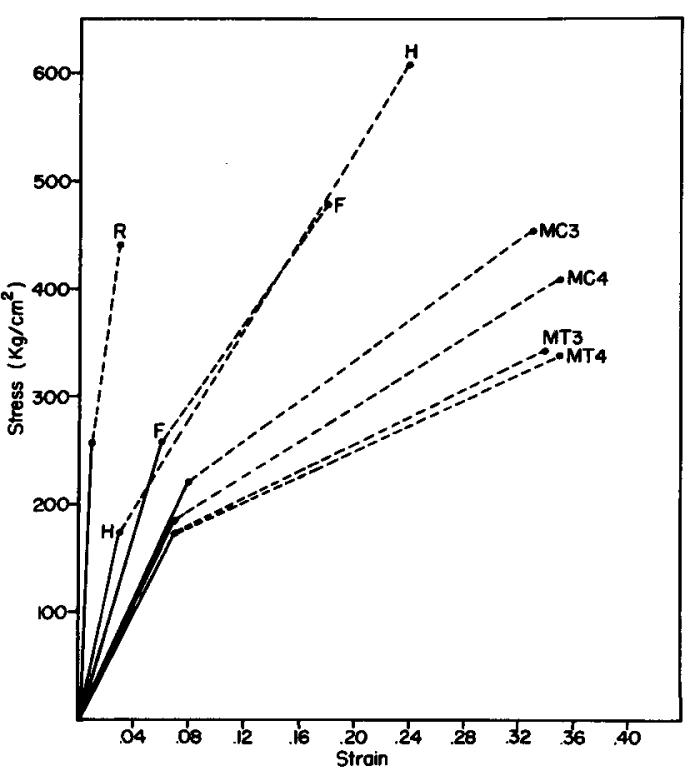

Figure 3. Stress: strain curve for bones pooled across $\mathrm{Ca}, \mathrm{P}$ levels, age and sex.-region of curve where bone exhibits plastic flow.-region of curve where bone exhibits elastic flow. 


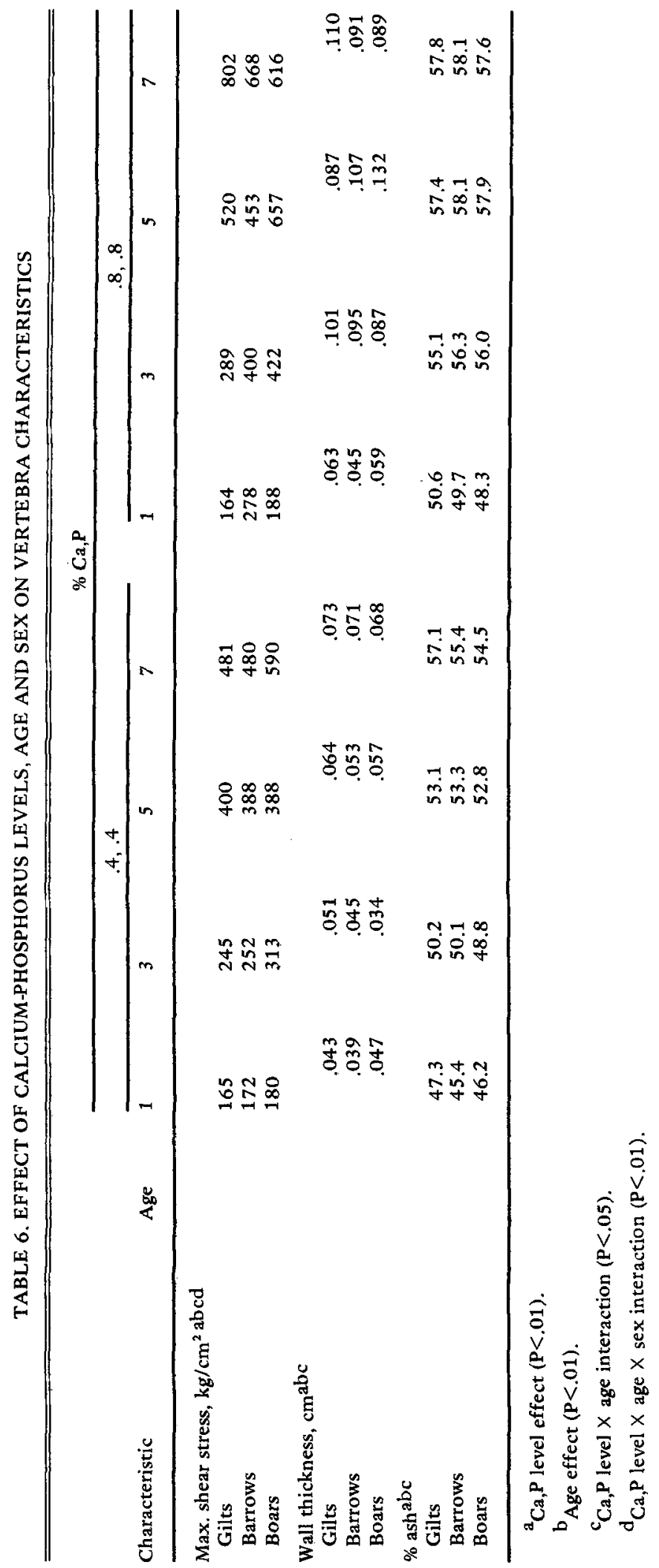


lower bending moment than the Hum and Fem, but a higher bending moment than the Rib.

Ultimate and yield stresses allow comparisons to be made between bones that differ greatly in size and shape. This can be demonstrated by a comparison of the Rib with the $\mathrm{MC}$ and $\mathrm{MT}$ bones. The Rib had a much lower bending moment than the MC and MT bones, but, when expressed as force per unit area, the yield stress of the Rib was greater than, and ultimate stress equivalent to, that of metacarpal and metatarsal bones. The modulus of elasticity of the Rib was much greater than that of all other bones because of the small amount of strain or bending that occurred in the Rib. This indicates that the Rib is a very brittle bone.

The Hum had a greater ultimate stress than the Fem. The yield stress of the Fem was greater than that of the Hum. These results indicate that the Hum withstood less force than the Fem before permanent damage (elastic flow) occurred (figure 3 ), but that the Hum withstood more force than the Fem after permanent damage had occurred (plastic flow). This relationship can be explained in part by the shape of the Hum. The top wall area at the point of loading in the Hum cross section (see cross section of Hum, figure 2) is much thinner than the sides and bottom. The Hum failed first at the top wall and began plastic flow (yield point) while the sides and bottom were undergoing elastic flow. The sides and bottom of the Hum withstood a greater force than the top.

From the data presented in table 5 , it is evident that any relationship between percentage of ash and any of the bone strength characteristics depends upon which bone is used. For example, while the Fem and Hum have a higher ultimate stess than MC, MT or Rib bone, their percentage of ash is smaller than that of the MC or MT bone but greater than that of the Rib. Tests for homogeneity of slopes between percentage of ash and all bone strength parameters except bending moment were nonsignificant, indicating that there is little relationship between percentage of ash and strength parameters. Currey (1969) reported an exponential relationship between strength and percentage of ash. The relationship between percentage of ash and bending moment was dependent not only on bone, as mentioned above, but also upon sex $(\mathrm{P}<.05)$.

The results of the hardness test with the vertebrae sections are shown in table 6. Maximum shear stress shows a different response from that seen in the mechanical tests with the other bones in that interactions occurred between $\mathrm{Ca}, \mathrm{P}$ level, age and sex. At A1, Ver of gilts and boars did not respond to increased levels of $\mathrm{Ca}, \mathrm{P}$. At A7, Ver from gilts showed a greater response to levels of $\mathrm{Ca}, \mathrm{P}$ than did those from barrows or boars. In fact, Ver from boars responded very little to level of $\mathrm{Ca}, \mathrm{P}$, and shear stress actually decreased between A5 and A7 for Ver from boars fed T2. Shear stress of Ver from barrows appeared to increase with the higher levels of $\mathrm{Ca}$ and $\mathrm{P}$ at all age periods. Percentage of ash in Ver from pigs fed $T 1$ tended to increase across all age periods, while among pigs fed $\mathrm{T} 2$, percentage of ash increased at A1, A3 and A5 but did not change between A5 and A7. Thickness of the cortical bone followed a response pattern similar to that observed for percentage of ash; the response was linear for bones from pigs fed $T 1$ and quadratic for those from pigs fed $\mathrm{T} 2$.

The effect of $\mathrm{Ca}, \mathrm{P}$ level and age upon the ultimate stress of each bone is shown in figure 4. In this three-dimensional histogram, many of the interactions noted earlier can be observed. In the Fem of pigs fed $\mathrm{T} 1$, ultimate stress increased across all age periods, while the ultimate stress of the Fem of pigs fed T2 increased between $A 1$ and $A 3$, leveled off between $\mathrm{A} 3$ and $\mathrm{A} 5$ and then decreased at A7. The Hum of pigs fed $T 1$ showed a response similar to that of the Fem, increasing across all age periods. The Hum of pigs fed $\mathrm{T} 2$ increased up to A5 and then leveled off between A5 and A7. The $M C$ and $M T$ bones showed no response to $\mathrm{Ca}, \mathrm{P}$ levels at $\mathrm{A} 1$. At $\mathrm{A} 3$, ultimate stress values for $M C$ and $M T$ bones were less than those for the same bones at A1. From A3 on, the ultimate stress of the MC and MT bones

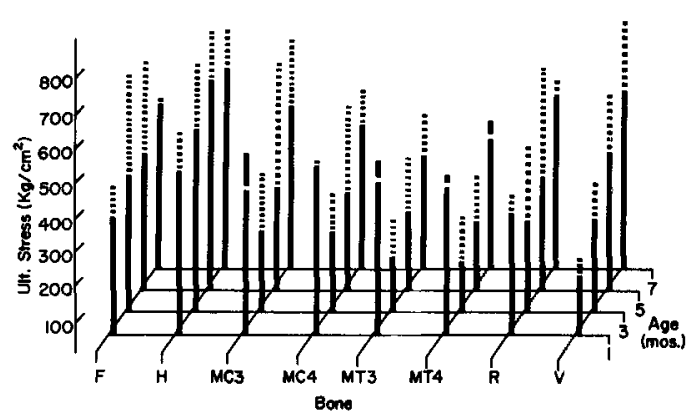

Figure 4. Effect of age and Ca,P levels on ultimate stress of various bones. $\square=$ pigs fed $T 1 .= \pm$ increase beyond $\mathrm{T} 1$ for pigs fed $\mathrm{T} 2$. 
increased in a linear manner regardless of $\mathrm{Ca}, \mathrm{P}$ level fed. Of all the bones, only the 4MT failed to show an increase in ultimate stress at A7 in pigs fed $\mathrm{T} 2$ as compared to those fed $\mathrm{T} 1$. The Rib of pigs fed $\mathrm{T} 1$ maintained a similar ultimate stress at $\mathrm{A} 1$ through $\mathrm{A} 5$ and then increased dramatically between A5 and A7. Among pigs fed $\mathrm{T} 2$, the Rib increased in ultimate stress across all age periods. The shear stress of Ver increased across all age periods regardless of $\mathrm{Ca}, \mathrm{P}$ level fed, and, in all cases, the Ver of pigs fed T2 had a greater shear stress than the Ver of those fed T1.

Thus, in assessing mineralization in bones of pigs at different age periods, it should be noted that the Fem, Hum and Rib were the only bones to show a response to levels of $\mathrm{Ca}$ and $\mathrm{P}$ at an early age (A1); hence, they would be the bones to choose for testing in 2-month-old pigs. At $\mathrm{A} 3$ or $\mathrm{A} 5$, all bones tended to respond to levels of $\mathrm{Ca}, \mathrm{P}$, and the bones of the front or hind feet, which are usually more accessible, could be selected. At A7, only the Hum, 3MC, $4 \mathrm{MC}, 3 \mathrm{MT}$ and Ver responded to levels of $\mathrm{Ca}, \mathrm{P}$. The results support the conclusion of Tanksley (1979) that differences in $\mathrm{Ca}$ and $\mathrm{P}$ requirements may depend upon the bone one uses to assess requirements, but do not support his conclusion that the Fem is a better indicator of bone development than are MC bones.

\section{Literature Cited}

Baker, J. L. and C. G. Haugh. 1979. Mechanical properties of bone: A review. Trans. Amer. Soc. Agr. Eng. 22:678.

Barr, A. J., J. H. Goodnight, J. P. Sall and J. T Helwig. 1976. A User's Guide to SAS. SAS Institute Inc., Raleigh, NC.

Burnett, E. A. 1908. The effect of food on breaking strength of bones. Agr. Exp. Sta. Bull. 107, Vol. 21, Article 1.

Cromwell, G. L., V. W. Hays, C. W. Scherer and J. R. Overfield. 1972. Effects of dietary calcium and phosphorus on performance and carcass, metacarpal and turbinate characteristics of swine. $J$. Anim. Sci. 34:746.

Currey, J. D. 1969. The mechanical consequences of variation in the mineral content of bone. J. Biomech. 2:1.

Evans, J. G. 1973. Mechanical Properties of Bone. Charles C. Thomas, Springfield, IL.

Granik, G. and I. Stein. 1973. Human ribs: Static testing as a promising medical application. J.
Biomech. 6:237.

Griffel, W. 1966. Handbook of Formulas for Stress and Strain. Frederick Ungar Publishing Co., New York.

Hayes, S. H., G. L. Cromwell, T. S. Stahly and T. H. Johnson. 1979. Availability of phosphorus in corn, wheat and barley for the chick. J. Anim. Sci. 49:992.

Henrikson, P. A. 1968. Periodontal disease and calcium dificiency. Acta Odontal. Scand. 26 (Suppl. 50): 1 .

Libal, G. W., E. R. Peo, Jr., R. P. Andrews and P. E. Vipperman, Jr. 1969. Levels of calcium and phosphorus for growing finishing swine. J. Anim. Sci. 28:331.

Liptrap, D. O., E. R. Miller, D. E. Ullrey, K. K. Keahey and J. A. Hoefer. 1970. Calcium levels for developing boars and gilts. J. Anim. Sci. 31:540.

Martin, R. B, and P. J. Atkinson. 1977. Age and sex-related changes in the structure and strength of the human femoral shaft. J. Biomech. 10:223.

Miller, E. R., D. E. Ullrey, C. L. Zutaut, B. V. Baltzer, D. A. Schmidt, J. A. Hoefer and R. W. Luecke. 1962. Calcium requirement of the baby pig. $J$. Nutr. 77:7.

Miller, E. R., D. E. Ullrey, C. L. Zutaut, B. V. Baltzer, D. A. Schmidt, J. A. Hoefer and R. W. Luecke. 1964. Phosphorus requirement of the baby pig. J. Nutr. 82:34.

Nimmo, R. D., E. R. Peo, Jr., B. D. Moser, P. J. Cunningham, D. G. Olson and T. D. Crenshaw. 1980. Effect of various levels of dietary calcium and phosphorus on performance, blood and bone parameters in growing boars. J. Anim. Sci. $51: 100$.

NRC. 1973. Nutrient Requirements of Domestic Animals, No. 2. Nutritional Requirements of Swine. National Academy of Sciences-National Research Council, Washington, DC.

Pond, W. G., F. E. Lovelace, E. R. Walder and L. Krook. 1969. Distribution of parenterally administered ${ }^{45} \mathrm{Ca}$ in bones of growing pigs. J. Anim. Sci. 29:298.

Steel, R.G.D. and J. G. Torrie. 1960. Principles and Procedures of Statistics. McGraw-Hill Book Co., New York.

Swanson, S.A.V. 1971. Biomechanical characteristics of bone. In R. M. Kennidi (Ed.) Advances in Biomedical Engineering. Academic Press, New York.

Tanksley, T. D. 1979. Nutrition and management of the breeding herd. Proc. Alabama Pork Ind. Conf., Auburn, AL.

Tanksley, T. D., Jr., J. Schroder and R. G. Robinson. 1976. Calcium and phosphorus requirements of large framed developing boars. Proc. Internat'l Pig Vet. Soc. Ames, IA.

Weir, J. D. de V., G. H. Bell and J. W. Chambers. 1949. The strength and elasticity of bone in rats on a rachitogenic diet. J. Bone Joint Surg. 31B:444. 